\title{
Desain Manajemen Risiko Pada Pengelolaan Sumber Air di Desa Sumberdodol Dengan Mengacu pada Standar ISO 31000
}

\author{
Aprilia V.A ${ }^{1)}$, Catur A ${ }^{2)}$, Brilianti N.P ${ }^{3)}$, Kurnia W.K ${ }^{4)}$, Ariyanto O.Y ${ }^{5)}$, Oktavena T.W ${ }^{6)}$ \\ Program Studi Manajemen \\ Fakultas Ekonomi dan Bisnis \\ Universitas Katolik Widya Mandala Madiun
}

\begin{abstract}
Abstrak
Pengelolaan sumber air di desa Sumberdodol Magetan merupakan salah satu badan usaha milik Desa Sumberdodol operasional pengelolaan sumber air bersih bagi warga Sumberdodol Magetan. Namun dalam operasional pengelolaan sumber air didesa belum memiliki sistem manajemen risiko sehingga berdampak pada kelangsungan penyaluran air ke pemukiman warga. Penelitian ini bertujuan untuk mengidentifikasi risiko, analisis risiko dan evaluasi risiko agar dapat dilakukan pencegahan dan penanggulangan dampak risiko pada setiap bagian di pengelolaan sumber air didesa Sumberdodol dengan menggunakan sistem manajemen risiko berstandar ISO 31000. Tahapan manajemen risiko mengacu pada ISO 31000 dimulai dari identifikasi risiko dengan metode Risk Breakdown Structure (RBS), analisis risiko dengan menggunakan matriks kuantifikasi risiko dan Risk Priority Number (RPN), serta evaluasi risiko dengan menggunakan peta risiko (risk map), risk mitigation strategy loggof ed in green, yellow, and red zone. Hasil penelitian menunjukkan bahwa pada pengelolaan sumber air Sumberdodol memiliki 18 peristiwa risiko yang terdiri dari 2 variabel yaitu keuangan dan operasional
\end{abstract}

Kata Kunci : pengelolaan sumber air Sumberdodol, Manajemen Risiko

\begin{abstract}
The management of water sources in the village of Sumberdodol Magetan is one of the business entities owned by the Sumberdodol Village, which operates the management of clean water sources for Sumberdodol Magetan residents. However, in the operational management of water resources in the village, there is no risk management system that has an impact on the continuity of water distribution to residential areas. This study aims to identify risk, risk analysis and risk evaluation so that the risk impact prevention and mitigation can be carried out in each part of the management of water resources in Sumberdodol village by using an ISO 31000 standard risk management system. The risk management stage refers to ISO 31000 starting with risk identification with method Risk Breakdown Structure (RBS), risk analysis using risk quantification matrix and Risk Priority Number (RPN), as well as risk evaluation using risk maps, loggof risk mitigation strategy ed ed in green, yellow, and red zone. The results showed that the management of Sumberdodol water resources had 18 risk events consisting of 2 variables, namely financial and operational
\end{abstract}

Keyword : water resources management of Sumberdodol, Risk management 


\section{PENDAhuluan}

\section{A. LATAR BELAKANG}

Risiko merupakan hal yang dapat terjadi dalam organisasi atau perusahaan kapan saja dan sulit untuk dihindari. Jika suatu perusahaan mengalami risiko yang besar hal ini dapat menyebabkan kebangkrutan suatu perusahaan tersebut. Maka dari itu risiko sangat penting untuk dikelola dalam suatu perusahaan. Menurut Hanafi (2014 : 8) menyatakan bahwa pengelolaan risiko dalam perusahaan bertujuan guna menciptakan sistem dan mekanisme dalam perusahaan sehingga risiko yang sewaktu-waktu terjadi dapat dikelola dan diantisipasi untuk meningkatkan nilai suatu perusahaan.

Dalam suatu perusahaan manajemen risiko dapat digunakan untuk beberapa hal yakni, yang pertama untuk meramalkan berapa frekuensi dan besarnya kemungkinan kerugian yang dialami jika terjadi peristiwa yang tak terduga sebelumnya. Yang kedua yakni menciptakan suatu dasar untuk membatasi atau mengurangi timbulnya risiko. Yang ketiga yakni menyediakan dasar untuk pengambilan keputusan guna memperkirakan risiko yang mungkin terjadi.

Setiap perusahaan pasti akan menghadapi risiko karena lingkungan kerjanya yang tidak pasti. Pengelolan air di desa Sumberdodol merupakan organisasi milik desa yang menyediakan air bersih bagi masyarakat desa Sumberdodol Magetan. Dalam hal ini, panitia pengelola sumber air di desa Sumberdodol belum bisa memberikan pelayan yang optimal bagi masyarakat desa tersebut. Hal tersebut dibuktikan dengan masih adanya kebocoran pipa dalam distribusi, meter air yang sering rusak, kekurangan biaya untuk membayar listirk, serta berhentinya pasokan air ke pelanggan dikarenakan faktor tertentu.

Dari pengamatan peneliti, diketahui juga bahwa pengelolaan sumber air ini belum memiliki sistem manajemen risiko yang memadai. Hal ini diketahui karena saat dilakukannya penelitian panitia pengelolaan sumber air tidak memiliki dokumen manajemen risiko. Seharusnya setiap organisasi wajib untuk membuat manajemen risiko yang memadai guna menjamin kelangsungan hidup organisasi dan bisa memberikan pelayanan yang optimal untuk masyarakat. Maka dari itu perlu dilakukan penelitian guna 
mendesain sistem manajemen risiko pada Pengelolaan Sumber Air di desa Sumberdodol dengan mengacu pada standar internasional.

Dengan adanya penelitian ini diperoleh manfaat berupa pemahaman yang baik tentang manajemen risiko berdasarkan standar ISO 31000 serta mampu menyusun perancangan sistem pencegahan dan pengendalian risiko. Penelitian sebelumnya terkait dengan topik ini telah dilakukan oleh Zainal Putra (2017), dengan judul Design of Risk Manajement Based on IS0 31000 in PDAM Tirta Meulaboh yang meneliti penerapan sistem manajemen risiko pada perusahaan pengelolaan air milik pemerintah sebagai masukan untuk program PDAM. Dapat kami jelaskan bahwa penelitian ini sama dengan penelitian sebelumnya dengan karakteristik perusahaan yang sama serta pembahasannya sama pula.

\section{B. TINJAUAN PUSTAKA}

\section{Pengertian Risiko dan Manajemen Risiko}

Risiko merupakan sebagian kejadian yang merugikan atau tidak tercapainya tujuan yang diharapkan (Tugiman 2009). Risiko berhubungan dengan ketidakpastian yang terjadi karena tidak tersedianya informasi yang menyangkut apa yang kan terjadi. Ketidakpastian yang dihadapi organisasi dapat mengakibatkan kerugian maupun keuntungan. Jika ketidakpastian tersebut menguntungkan maka disebut kesempatan tetapi jika merugikan maka disebut risiko.Menurut Hanafi (2014 : 1) menyatakan bahwa risiko merupakan sebagian kejadian yang merugikan. Selain itu definisi yang lain yang sering digunakan untuk analisis investasi yakni kemungkinan hasil yang diperoleh menyimpang dari yang diharapkan.

Mamduh (2017) menyatakan bahwa manajemen risiko merupakan suatu sistem pengendalian risiko organisasi yang dihadapi oleh orgnisasi secara komprohensif untuk tujuan meningkatkan nilai perusahaan. Sedangkan Gibson (2017) menyatakan bahwa manajemen risiko sebagai kegiatan praktis tentang identifikasi penilaian, pengontrolan dan peringanan risiko. Pada dasarnya manajemen risiko dilakukan melalui proses identifikasi risiko, evaluasi, pengukuran risiko dan pengelolaan risiko. 
Setiap oganisasi pasti mempunyai risiko dan harus bisa mengelola risiko. Apabila suatu organisasi gagal mengelola risiko akan merugikan peruahaan itu sendiri. Ada enam cara mengelola risiko yakni penghindaran, ditahan, diversifikasi, transfer risiko, pengendalian risiko dan pendanaan risiko hal tersebut di kemukakan oleh Hanafi (2014 : $11)$.

\section{ISO 31000 dan Proses Manajemen Risiko}

Internasional Standar Organization (ISO) telah menyusun sebuah standar manajemen risiko hal tersebut disertai dengan adanya berbagai standar manajemen risiko dan konsensus global manajemen risiko. Setelah melalui proses voting dan revisi dari semuan anggota ISO, standar ini diluncurkan sebagai standar internasional (Susilo, L.J. dan Kaho, V.R., 2010 : 6). Standar ISO tidak menafikan standar manajemen risiko yang dibuat untuk keperluan spesifik dan khusus hal tersebut menyatakan bahwa standar ISO 31000 merupakan standar manajemen risiko yang generik. Prespektif dari ISO 31000 lebih luas dan lebih konseptual dibandingkan dengan standar manajemen risiko yang lain. Terdapat lima kegiatan risiko yang termasuk dalam proses manajemen risiko yaitu komunikasi dan konsultasi, menentukan konteks, asesmen risiko, perlakuan risiko dan monitoring serta review. Identifikasi risiko, analisis risiko dan evaluasi risiko ketiga hal tersebut termasuk dalam bagian asesmen risiko.

Gambar 1.Proses Manajemen Risiko Menurut ISO 31000

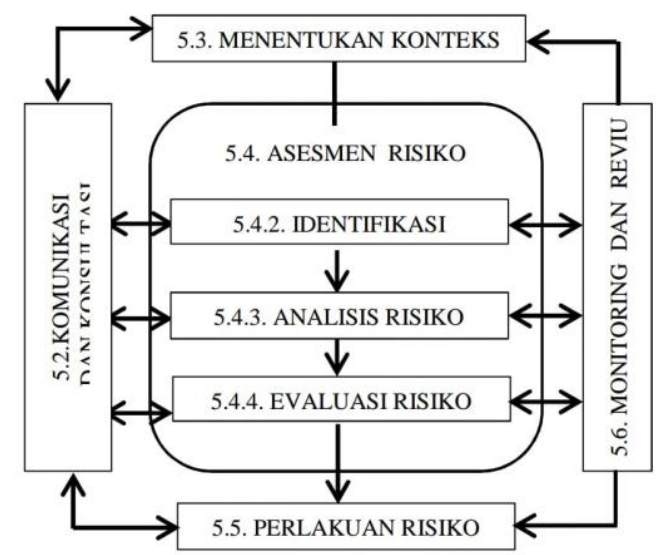

Peltier (2017) menyatakan bahwa terdapat enam tahap dalam proses analisis risiko yakni definisi aset, identifikasi ancaman, menentukan probabilitas kejadian, 
menentukan dampak dari ancaman, rekomendasi pengendalian dan dokumentasi. Dalam mitigasi risiko terdapat lima metode yakni penerimaan risiko, pengurangan risiko, penghindaran risiko, pembatalan risiko, dan perencanaan risiko.

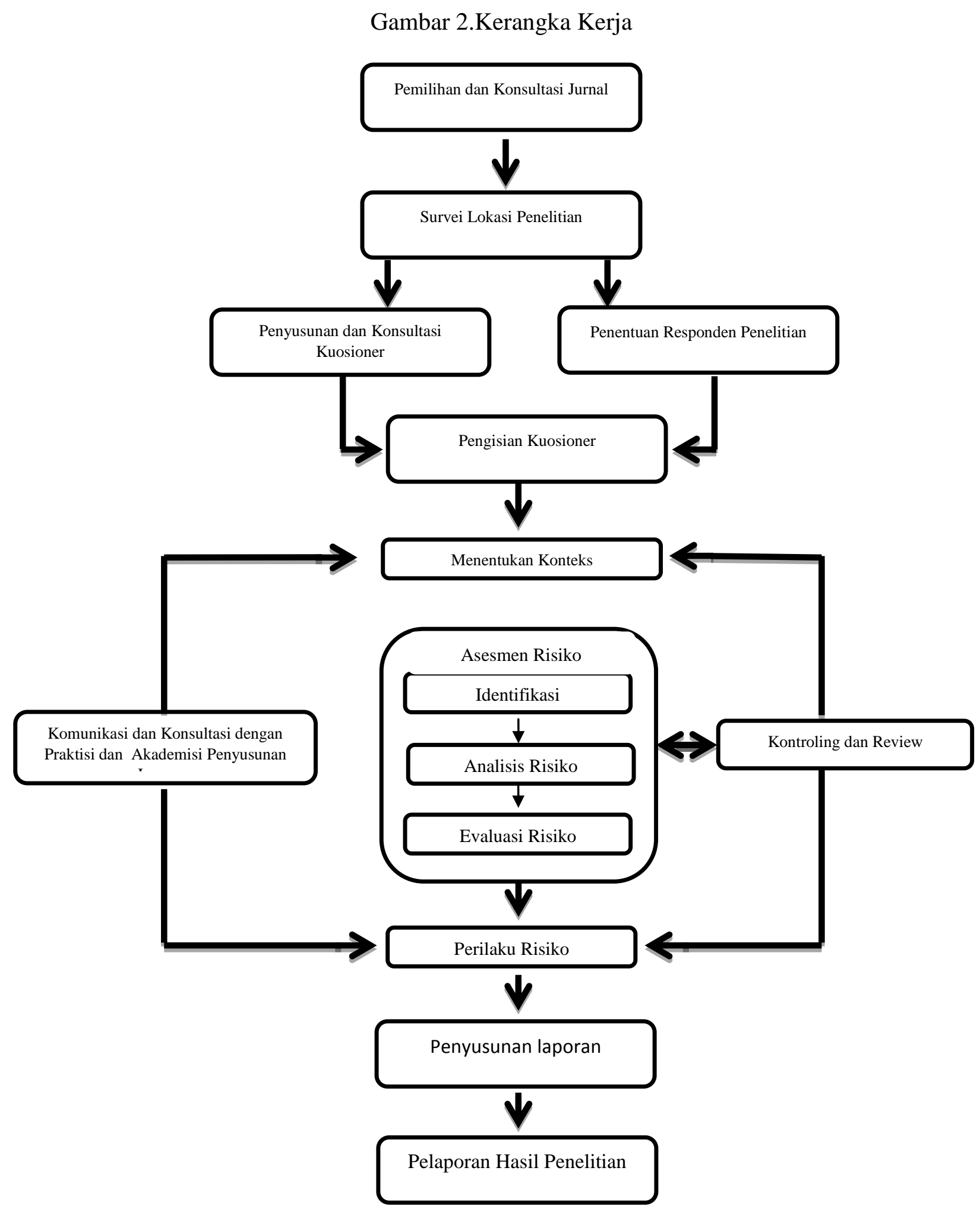




\section{METODOLOGI PENELITIAN}

Metode penelitian risiko yang digunakan mengacu pada ISO 31000. Tahapan dalam penelitian dimulai dari identifikasi risiko, analisis risiko dan evaluasi risiko. Identifikasi risiko bertujuan untuk mengetahui risiko yang mungkin timbul dalam suatu kegiatan. Setelah mengetahui risiko yang bisa diidentifikasi risiko yang harus dikelola melalui proses yang sistematis dan terstruktur. Sasaran identifikasi risiko adalah mengembangkan daftar sumber risiko dan kejadian yang memiliki dampak terhadap pencapaian sasaran dan target yang teridentifikasi. Data yang diperoleh pada proses ini adalah daftar kemungkinan risiko serta dampak yang mungkin terjadi.

Identifikasi risiko menggunakan metode Risk Breakdown Structure (RBS), kemudian melakukan brainstorming dengan para pengurus POKMAS TIRTO RAHAYU. Analisis risiko merupakan proses untuk memahami sifat risiko dan menentukan tingkat risiko dan strategi yang tepat dalam memperlakukan risiko tersebut. Analisis risiko menggunakan matriks kuantifikasi risiko, kemudian risiko dikelompokkan dalam zona merah, kuning, dan hijau sesuai tingkatannya.

Evaluasi risiko bertujuan untuk membantu dalam pengambilan keputusan berdasarkan analisis resiko dengan menentukan risiko mana yang memerlukan perlakuan dan bagaimana prioritas perlakuan tersebut.

Tabel 1 Matriks Kuantitatif

\begin{tabular}{|c|c|c|c|c|c|}
\hline \multirow{2}{*}{ KEMUNGKINAI } & \multicolumn{5}{|c|}{ DAMPAK } \\
\hline & Sangat Kecil & Kecil & Sedang & Besar & Sangat Besar \\
\hline & 1 & 2 & 3 & 4 & 3 \\
\hline Sangat Jarang 1 & 5 & 10 & 15 & 20 & 25 \\
\hline Jarang & 4 & 8 & 12 & 16 & 20 \\
\hline Mungkin & 3 & 6 & 9 & 12 & 15 \\
\hline Mungkin sekali 4 & 2 & 4 & 6 & 8 & 10 \\
\hline hampir pasti 5 & 1 & 2 & 3 & 4 & 5 \\
\hline
\end{tabular}

Sumber: Li Guo (2015)

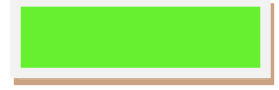

Cukup

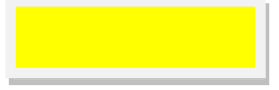

Sedang

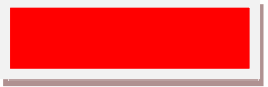

Tinggi 


\section{HASIL PENELITIAN DAN PEMBAHASAN}

\section{A. Gambaran Umum Organisasi}

Pengelolaan Sumber Air di desa Sumberdodol merupakan badan usaha milik pemerintah desa Sumberdodol Magetan yang didirikan pada tahu 1985 dengan nama POKMAS Tirto Rahayu. Berdasarkan data per Januari 2015, organisasi ini memiliki cakupan pelayanan untuk dua RW yakni RW 3 dan RW 4.

Pengelolaan sumber air di desa Sumberdodol memiliki 2 tandon air di masingmasing RW, setiap tandon dapat menampung air sebanyak $18 \mathrm{~m}^{3}$. Organisasi ini dijalankan oleh 18 orang sebagi pengelola sukarela yang ditunjuk oleh kepala desadimana 14 orang di RW 4 dan 4 orang di RW 3.

\section{B. Identifikasi Risiko}

Indetifikasi risiko pada penelitian ini dilakukan dengan cara pengujian dokumen, metode Risk Breakdown Strukture (RBS) dimana RBS merupakan pengelompokan risiko dalam suatu komposisi hirarkis risiko organisasi yang logis, sistematis dan terstruktur secara alami sesuai dengan struktur organisasi. Pada penelitian ini metode RBS dilakukan dengan cara wawancara dan brainstorming dengan pihak pemangku risiko terkait dari hasil pengujian dokumen, diperoleh informasi bahwa terdapat bagian kerja dibawah POKMAS Tirto Rahayu yang memiliki potensi risiko yakni bagian keuangan dan bagian operasional. Adapun RBS untuk POKMAS Tirto Rahayu sebagaimana gambar 3. Berdasarkan hasil wawancara dan brainstorming dengan pemangku risiko dapat teridentifikasi secara keseluruhan sebanyak 18 peristiwa risiko.

Gambar 3 Risk Breackdown Strukture

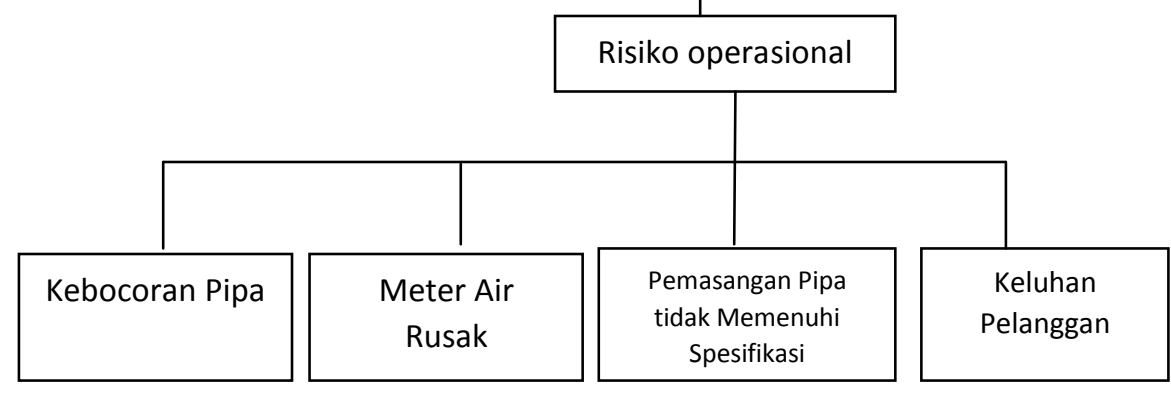




\section{Analisis Risiko}

Pada penelitian ini proses analisis risiko menggunakan metode kuantitatif dengan menggunakan parameter kulitatif. Penilaian dilakukan dengan penyebaran kuesioner untuk mendapatkan informasi dari pemangku risiko terkait. Responden berjumlah 18 orang yang merupakan pemangku risiko pada POKMAS Tirto Rahayu. Kuesioner dibagi menjadi 2 yaitu kemungkinan risiko dan dampak.

Kuesioner tersebut dilakukan uji normalitas dengan menggunakan software SPSS. Uji normalitas yang dilakukan dengan metode Kolmogorov-Smirnovmemberikan hasil bahwa data terdistribusi secara normal baik variabel risiko maupun variabel dampak, sebagaimana ditunjukkan dalam gambar 4 dan gambar 5 .

Gambar 4 Test of Normality

\begin{tabular}{|c|c|c|c|c|c|c|}
\hline \multicolumn{7}{|c|}{ Coefficients $^{a}$} \\
\hline \multirow{2}{*}{\multicolumn{2}{|c|}{ Model }} & \multicolumn{2}{|c|}{ Unstandardized Coefficients } & \multirow{2}{*}{$\begin{array}{c}\begin{array}{c}\text { Standardized } \\
\text { Coefficients }\end{array} \\
\text { Beta }\end{array}$} & \multirow[b]{2}{*}{$\mathrm{t}$} & \multirow[b]{2}{*}{ Sig. } \\
\hline & & B & Std. Error & & & \\
\hline 1 & (Constant) & 84.030 & 21.611 & & 3.888 & .002 \\
\hline & Resiko & .023 & .484 & .013 & .048 & .962 \\
\hline
\end{tabular}

Gambar 5 Test of Normality

\begin{tabular}{|c|c|c|c|c|c|c|}
\hline \multicolumn{7}{|c|}{ Coefficients $^{a}$} \\
\hline \multirow{2}{*}{\multicolumn{2}{|c|}{ Model }} & \multicolumn{2}{|c|}{ Unstandardized Coefficients } & \multirow{2}{*}{$\begin{array}{c}\text { Standardized } \\
\text { Coefficients } \\
\text { Beta }\end{array}$} & \multirow[b]{2}{*}{$\mathrm{t}$} & \multirow[b]{2}{*}{ Sig. } \\
\hline & & B & Std. Error & & & \\
\hline 1 & (Constant) & 43.545 & 13.626 & & 3.196 & .007 \\
\hline & Dampak & .008 & .159 & .013 & .048 & .962 \\
\hline
\end{tabular}

Dari gambar diatas, dirunjukkan bahwa masing-masing angka signifikan uji kolmogorov-semirnov sig. $=0,962>0,05$ yang berarti pernyataan dalam kuesioner tersebut valid. 
Risiko yang telah dianalisis, kemudian dimasukkan pada zona merah, kuning atau hijau. Semua risiko yang berada pada zona merah menjadi prioritas utama untuk mendapatkan perlakuan khusus yaitu berupa penanganan lebih lanjut, sehingga dapat disebut Risk Priority Numbers (RPN), sebagaimana disajikan tabel 2.

Tabel 2Risk RPN for events in the green, yellow, and red zone

\begin{tabular}{|c|c|c|c|c|c|c|}
\hline No & Variabel & Uraian & $\mathrm{KK}^{*}$ & $\mathrm{D}^{*}$ & $\begin{array}{c}\mathrm{RPN} \\
*\end{array}$ & Rangking \\
\hline 1 & Keuangan & Tunggakan akun pelanggan & 1,2 & 1,4 & 2 & 1 \\
\hline 2 & Keuangan & Kekurangan dana pemeliharaan & 1,8 & 2,06 & 4 & 1 \\
\hline 3 & Keuangan & Kekurangan biaya listrik atau PLN & 1,8 & 2,6 & 5 & 1 \\
\hline 4 & Keuangan & Pelanggan enggan membayar tagihan air & 1,46 & 1,8 & 3 & 1 \\
\hline 5 & Operasional & Air keruh atau kotor & 1,6 & 2,13 & 3 & 1 \\
\hline 6 & Operasional & Kebocoran pipa dalam distribusi & 4,13 & 3,86 & 16 & 4 \\
\hline 7 & Operasional & Meter air rusak & 4,06 & 3,46 & 14 & 3 \\
\hline 8 & Operasional & $\begin{array}{l}\text { Pompa dsitribusi tidak dapat digunakan } \\
\text { terus-menerus }\end{array}$ & 3,13 & 3,4 & 11 & 3 \\
\hline 9 & Operasional & Terjadinya banjir & 1,86 & 2,5 & 5 & 1 \\
\hline 10 & Operasional & $\begin{array}{l}\text { Kesalahan merekam meteran air di rumah } \\
\text { pelanggan }\end{array}$ & 2,2 & 2,13 & 5 & 1 \\
\hline 11 & Operasional & $\begin{array}{l}\text { Pemasangan pipa distribusi tidak } \\
\text { memenuhi spesifikasi }\end{array}$ & 2,07 & 2,67 & 4 & 1 \\
\hline 12 & Operasional & $\begin{array}{l}\text { Pemantauan dengan perangkat lunak } \\
\text { untuk tekanan air belum tersedia }\end{array}$ & 4,26 & 2,2 & 9 & 2 \\
\hline 13 & Operasional & Terjadi koneksi ilegal & 1,7 & 1,86 & 3 & 1 \\
\hline 14 & Operasional & Pasokan air ke lapangan berhenti & 2,4 & 2,3 & 5 & 1 \\
\hline 15 & Operasional & Meteran pengukur air tandon rusak & 2,73 & 2,53 & 7 & 2 \\
\hline 16 & Operasional & $\begin{array}{l}\text { Sebagian pelanggan tidak dapat pasokan } \\
\text { air }\end{array}$ & 2 & 1,86 & 4 & 1 \\
\hline 17 & Operasional & Keluhan pelanggan tentang pelayanan & 2,67 & 2,73 & 7 & 2 \\
\hline 18 & Operasional & Keluhan pelanggan tentang pasokan air & 1,86 & 2 & 4 & 1 \\
\hline
\end{tabular}




\section{Evaluasi Risiko}

Evaluasi risiko ini bertujuan guna menentukan prioritas pengelolaan risiko sehingga diketahui risiko mana saja yang perlu mendapatkan perhatian dan penangan lebih lanjut. Tahap ini dilakukan untuk mengetahui berapa jumlah risiko yang hampir pasti, mungkin sekali, mungkin, jarang dan sangat jarang. Klasifikasi risiko tersebut dapat dilihat pada peta risiko (risk map) yang disajikan di tabel 3.

Dari total 18 potensi risiko yang berhasil diidentifikasi, terdapat sebanyak 10 potensi risiko yang masuk dalam zona hijau, terdiri dari bagian keuangan memiliki 3 potensi risiko yakni R1, R2, dan R4 dan bagian opersional memiliki 7 potensi risiko yakni R5, R9, R10, R13, R14, R16 dan R18. Sebanyak 7 potensi risiko masuk dalam zona kuning yang terdiri dari bagian keuangan terjadi 1 potensi risiko yaitu R3 dan bagian operasional sebanyak 6 potensi risiko yaitu R7, R11, R12, R15 dan R17. Dari keseluruhan yang masuk kedalam zona merah hanya 1 potensi risiko yakni R6 pada bagian operasional.

Kemudian potensi risiko yang masuk dalam zona hijau, kuning, dan merah dibuat peringkat sesuai dengan nilai RPN yang diperoleh guna menentukan prioritas risiko. Dari tabel 2 diatas terdapat 12 potensi risiko yang menepati peringkat pertama yakni R1, R2, R3, R4, R5, R9, R10, R11, R13, R14, R16 dan R18. Sedangkan pada peringkat kedua terdapat 3 potensi risiko yakni R12, R15, dan R17 dan pada peringkat ketiga terdapat 2 potensi risiko yakni R7 dan R8, serta sisanya 1 potensi risiko masuk kedalam peringkat keempat yaitu R6. Terhadap potensi risiko yang masuk dalam zona merah tersebut harus mendapatkan perhatian serius dari pihak manajemen untuk dapat dilakukan penanganan dengan segera. 
Tabel 3 Risk Map of water resources management Sumber dodol

\begin{tabular}{|c|c|c|c|c|c|}
\hline \multirow[t]{3}{*}{ Kemungkinan } & \multicolumn{5}{|c|}{ Dampak } \\
\hline & Sangat Kecil & Kecil & Sedang & Besar & Sangat Besar \\
\hline & 1 & 2 & 3 & 4 & 5 \\
\hline Hampir pasti & 5 & & & & \\
\hline $\begin{array}{l}\text { Mungkin } \\
\text { sekali }\end{array}$ & 4 & ${ }^{6} \mathrm{R} 12$ & ${ }^{6} \mathbf{R} 7$ & ${ }^{6} \mathbf{R 6}$ & \\
\hline Mungkin & 3 & ${ }^{6} \mathrm{R} 15$ & "R8"R17 & & \\
\hline Jarang & 2 & $\begin{array}{c}\text { *R2 "R5 } \\
\text { "R9 "R10 } \\
\text { "R13 "R14 } \mathrm{R} 14 \\
\text { "R16 "R18 }\end{array}$ & $\begin{array}{c}* R 3 \\
{ }^{6} \mathrm{R} 11\end{array}$ & & \\
\hline Sangat jarang & 1 & $* \mathbf{R} 1 * \mathbf{R} 4$ & & & \\
\hline
\end{tabular}

Gambar 6 Diagram Ranking Risiko

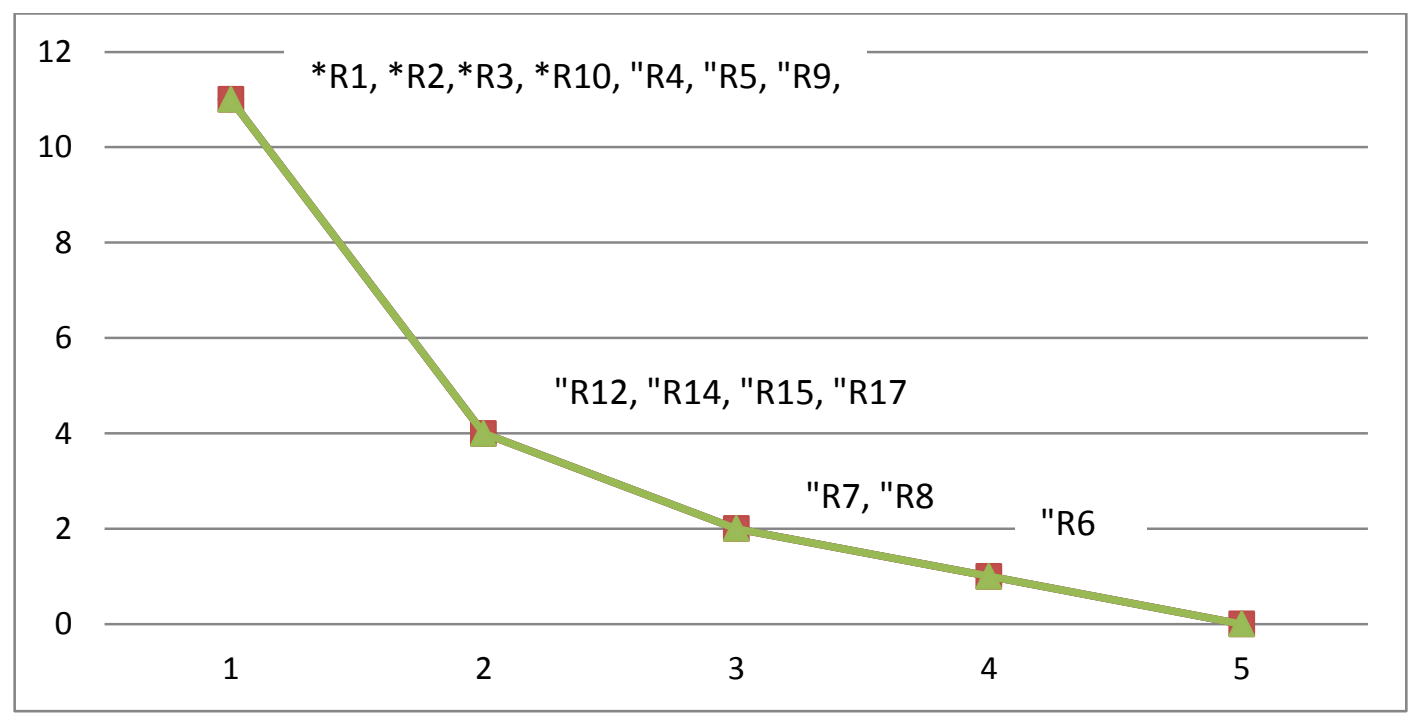


Tabel 3 Ranking Risiko

\begin{tabular}{|c|c|c|}
\hline Peringkat & Uraian kejadian & Dampak \\
\hline \multirow[t]{10}{*}{1} & Tunggakan akun pelanggan & $\begin{array}{l}\text { Terbatasnya dana pelaksanaan } \\
\text { dalam operasional oleh pengelola }\end{array}$ \\
\hline & Kekurangan dana pemeliharaan & $\begin{array}{l}\text { Pemeliharaan alat operasional } \\
\text { terganggu dan pasokan air tidak } \\
\text { dapat didistribusikan secara } \\
\text { optimal. }\end{array}$ \\
\hline & Kekurangan biaya listrik atau PLN & $\begin{array}{l}\text { Beban tunggakan listrik bagi } \\
\text { pengelola dan terancam } \\
\text { pemutusan saluran listrik }\end{array}$ \\
\hline & Pelanggan enggan membayar tagihan air & $\begin{array}{l}\text { Pemutusan status pelanggan oleh } \\
\text { pengelola }\end{array}$ \\
\hline & Terjadinya banjir & $\begin{array}{l}\text { Pasokan air pada tandon meluap } \\
\text { dan terbuang serta air tercampur } \\
\text { dengan tanah }\end{array}$ \\
\hline & $\begin{array}{l}\text { Kesalahan merekam meteran air di rumah } \\
\text { pelanggan }\end{array}$ & $\begin{array}{l}\text { Pelanggan mendapat tagihan } \\
\text { meteran air terlalu banyak atau } \\
\text { terlalu sedikit }\end{array}$ \\
\hline & $\begin{array}{l}\text { Pemasangan pipa distribusi tidak } \\
\text { memenuhi spesifikasi }\end{array}$ & $\begin{array}{l}\text { Dalam pendistribusian pasokan air } \\
\text { pipa mudah bocor }\end{array}$ \\
\hline & Terjadi koneksi ilegal & $\begin{array}{l}\text { Pasokan air yang masuk kepada } \\
\text { pelanggan berkurang }\end{array}$ \\
\hline & Sebagian pelanggan tidak dapat pasokan air & 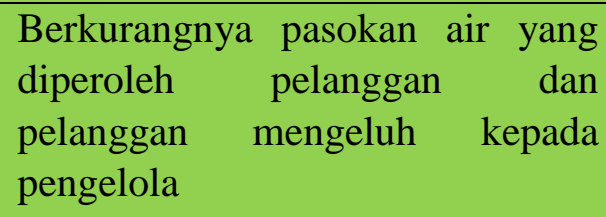 \\
\hline & Keluhan pelanggan tentang pasokan air & $\begin{array}{l}\text { Pelanggan mendapat giliran untuk } \\
\text { m endapatkan air }\end{array}$ \\
\hline \multirow[t]{2}{*}{2.} & $\begin{array}{l}\text { Pemantauan dengan perangkat lunak untuk } \\
\text { tekanan air belum tersedia }\end{array}$ & $\begin{array}{l}\text { Pengambilan keputusan dalam } \\
\text { pengelolaan air tidak bisa tepat } \\
\text { waktu }\end{array}$ \\
\hline & Meteran pengukur air tandon rusak & $\begin{array}{l}\text { Jumlah air yang masuk ke tandon } \\
\text { tidak dapat diukur atau tidak } \\
\text { diketahui }\end{array}$ \\
\hline
\end{tabular}




\begin{tabular}{|l|l|l|}
\hline \multirow{2}{*}{3.} & Keluhan pelanggan tentang pelayanan & $\begin{array}{l}\text { Pelanggan mengalami } \\
\text { keterlambatan mendapatkan } \\
\text { pasokan air }\end{array}$ \\
\cline { 2 - 3 } & $\begin{array}{l}\text { Peter air rusak } \\
\text { terus-menerus }\end{array}$ & $\begin{array}{l}\text { Kesalahan pengukuran pasokan } \\
\text { air yang digunakan pelanggan }\end{array}$ \\
\hline 4. & $\begin{array}{l}\text { Kebanyakan pelanggan yang } \\
\text { berada didaerah paling atas tidak } \\
\text { mendapat pasokan air }\end{array}$ \\
\hline & Kebocoran pipa dalam distribusi & $\begin{array}{l}\text { Pasokan air kepelanggan berhenti } \\
\text { karena kebocoran dan pembetulan } \\
\text { pipa distribusi air }\end{array}$ \\
\hline
\end{tabular}

\section{E. Perlakuan Risiko}

Sistem perlakuan risiko dibuat guna membantu pengelola dalam hal mengambil keputusan. Karena secara umum potensi risiko teridentifikasi berdasarkan kejadian yang pernah terjadi sebelumnya, maka stategi pemilihan perlakuan risiko yang dilakukan dalam penelitian ini adalah dengan cara mitigasi risiko, sebagaiman disajikan pada tabel 4.

Tabel 4 risk mitigation strategy loggof ed in green, yellow, and red zone

\begin{tabular}{|c|c|c|c|c|c|c|}
\hline No & Unit & Risiko & Penyebab & Dampak & $\begin{array}{c}\text { JenisTindak } \\
\text { an }\end{array}$ & Solusi Strategis \\
\hline 1 & Keuangan & $\begin{array}{l}\text { Tunggakan } \\
\text { akun } \\
\text { pelanggan }\end{array}$ & $\begin{array}{l}\text { Pelanggan enggan } \\
\text { membayar } \\
\text { dikarenakan } \\
\text { persepsi pelanggan } \\
\text { bahwa air } \\
\text { merupakan aset } \\
\text { desa sendiri } \\
\text { sehingga } \\
\text { pembayaran bisa } \\
\text { ditunda atau } \\
\text { mendahulukan } \\
\text { pembayaran listrik. }\end{array}$ & $\begin{array}{l}\text { Terbatasnya } \\
\text { dana } \\
\text { pelaksanaan } \\
\text { dalam } \\
\text { operasional } \\
\text { oleh } \\
\text { pengelola }\end{array}$ & Mendanai & $\begin{array}{l}\text { Membentukan tim } \\
\text { penagihan } \\
\text { lapangan yang } \\
\text { kusus untuk } \\
\text { pembayaran air } \\
\text { dan memberikan } \\
\text { sosialisasi kepada } \\
\text { masyarakat } \\
\text { bahwa } \\
\text { pengelolaan air } \\
\text { desa akan } \\
\text { berjalan lancar } \\
\text { apabila }\end{array}$ \\
\hline
\end{tabular}




\begin{tabular}{|c|c|c|c|c|c|c|}
\hline & & & & & & $\begin{array}{l}\text { pembayaran juga } \\
\text { lancar. }\end{array}$ \\
\hline 2 & Keuangan & $\begin{array}{l}\text { Kekurangan } \\
\text { dana } \\
\text { pemeliharaan }\end{array}$ & $\begin{array}{l}\text { Kekurangan dana } \\
\text { pemeliharaan } \\
\text { disebabkan } \\
\text { pelanggan yang } \\
\text { enggan membayar } \\
\text { dan keterlambatan } \\
\text { bantuan dana dari } \\
\text { pemerintah. }\end{array}$ & $\begin{array}{l}\text { Pemeliharaa } \\
\mathrm{n} \text { alat } \\
\text { operasional } \\
\text { terganggu } \\
\text { dan pasokan } \\
\text { air tidak } \\
\text { dapat } \\
\text { didistribusik } \\
\text { an secara } \\
\text { optimal. }\end{array}$ & Mendanai & $\begin{array}{l}\text { Pembayaran } \\
\text { tagihan air harus } \\
\text { dikelola dengan } \\
\text { baik dan } \\
\text { pengajuan dana } \\
\text { kepada } \\
\text { pemerintah secara } \\
\text { teratur dan tidak } \\
\text { mendadak. }\end{array}$ \\
\hline 3 & Keuangan & $\begin{array}{l}\text { Kekurangan } \\
\text { biaya listrik } \\
\text { atau PLN }\end{array}$ & $\begin{array}{l}\text { Kurangnya atau } \\
\text { terlambatnya } \\
\text { pembayaran air } \\
\text { oleh pelanggandan } \\
\text { adanya } \\
\text { penggantian pipa } \\
\text { yang rusak secara } \\
\text { mendadak }\end{array}$ & $\begin{array}{l}\text { Beban } \\
\text { tunggakan } \\
\text { listrik bagi } \\
\text { pengelola } \\
\text { dan } \\
\text { terancam } \\
\text { pemutusan } \\
\text { saluran } \\
\text { listrik }\end{array}$ & Mengalihkan & $\begin{array}{l}\text { Membuat pos } \\
\text { cadangan biaya } \\
\text { dalam system } \\
\text { keuangan. } \\
\text { Untuk } \\
\text { pembayaran } \\
\text { listrik dan } \\
\text { perbaikan alat } \\
\text { operasional }\end{array}$ \\
\hline 4 & Keuangan & $\begin{array}{l}\text { Pelanggan } \\
\text { enggan } \\
\text { membayar } \\
\text { tagihan air }\end{array}$ & $\begin{array}{l}\text { Pelanggan enggan } \\
\text { membayar tagihan } \\
\text { karena persepsi } \\
\text { pelanggan bahwa } \\
\text { air merupakan aset } \\
\text { desa sendiri } \\
\text { sehingga } \\
\text { pembayaran bisa } \\
\text { ditunda atau } \\
\text { mendahulukan } \\
\text { pembayaran listrik } \\
\text { ke PLN. }\end{array}$ & $\begin{array}{l}\text { Pemutusan } \\
\text { status } \\
\text { pelanggan } \\
\text { oleh } \\
\text { pengelola }\end{array}$ & Mendanai & $\begin{array}{l}\text { Memberikan } \\
\text { sosialisasi kepada } \\
\text { masyarakat akan } \\
\text { pentingnya biaya } \\
\text { operasional yang } \\
\text { bersumber dari } \\
\text { pembayaran } \\
\text { tagihan air tiap } \\
\text { bulan. }\end{array}$ \\
\hline 5 & Operasional & $\begin{array}{l}\text { Air keruh / } \\
\text { kotor }\end{array}$ & $\begin{array}{l}\text { Ketika hujan air di } \\
\text { sumber induk } \\
\text { tercampur dengan } \\
\text { tanah }\end{array}$ & $\begin{array}{l}\text { Banyak } \\
\text { pelanggan } \\
\text { yang } \\
\text { mengeluh } \\
\text { kepada } \\
\text { pengelola } \\
\text { dan }\end{array}$ & Mendanai & $\begin{array}{l}\text { Menyediakan } \\
\text { saringan pada } \\
\text { pipa yang ada } \\
\text { disumber air. }\end{array}$ \\
\hline
\end{tabular}




\begin{tabular}{|c|c|c|c|c|c|c|}
\hline & & & & $\begin{array}{l}\text { pembersihan } \\
\text { seluruh pipa } \\
\text { distribusi }\end{array}$ & & \\
\hline 6 & Operasional & $\begin{array}{l}\text { Kebocoran } \\
\text { pipa dalam } \\
\text { distribusi }\end{array}$ & $\begin{array}{l}\text { Adanya penggalian } \\
\text { jalan yang } \\
\text { mengenai saluran } \\
\text { pipa, pipa terinjak } \\
\text { atau terlindas } \\
\text { kendaraan dan } \\
\text { kualitas pipa yang } \\
\text { tidak mmenuhi } \\
\text { standar }\end{array}$ & $\begin{array}{l}\text { Pasokan air } \\
\text { kepelanggan } \\
\text { berhenti } \\
\text { karena } \\
\text { kebocoran } \\
\text { dan } \\
\text { pembetulan } \\
\text { pipa } \\
\text { distribusi air }\end{array}$ & Mengalihkan & $\begin{array}{l}\text { Perlu adanya } \\
\text { sosialisi kepada } \\
\text { masyarakat } \\
\text { setempat letak } \\
\text { jalur pipa air agar } \\
\text { masyarakat lebih } \\
\text { berhati-hati dalam } \\
\text { melakukan } \\
\text { aktivitas } \\
\text { penggalian tanah } \\
\text { dan mobilitas } \\
\text { kendaraan, serta } \\
\text { penggantian pipa } \\
\text { yang sudah lama } \\
\text { dengan pipa baru } \\
\text { yang memenuhi } \\
\text { standart. }\end{array}$ \\
\hline 7 & Operasional & $\begin{array}{l}\text { Meter air } \\
\text { rusak }\end{array}$ & $\begin{array}{l}\text { Meteran air sudah } \\
\text { terlalu tua }\end{array}$ & $\begin{array}{l}\text { Kesalahan } \\
\text { pengukuran } \\
\text { pasokan air } \\
\text { yang } \\
\text { digunakan } \\
\text { pelanggan }\end{array}$ & Mengganti & $\begin{array}{l}\text { Penggantian } \\
\text { meter air dengan } \\
\text { meteran yang } \\
\text { baru dan } \\
\text { memenuhi } \\
\text { standart. }\end{array}$ \\
\hline 8 & Operasional & $\begin{array}{l}\text { Pompa } \\
\text { distribusi } \\
\text { tidak dapat } \\
\text { digunakan } \\
\text { terus-menerus }\end{array}$ & $\begin{array}{l}\text { Pemasangan } \\
\text { pompa yang tidak } \\
\text { sesuai dengan } \\
\text { standar teknis dan } \\
\text { digunakan secara } \\
\text { terus menerus }\end{array}$ & $\begin{array}{l}\text { Kebanyakan } \\
\text { pelanggan } \\
\text { yang berada } \\
\text { didaerah } \\
\text { paling atas } \\
\text { tidak } \\
\text { mendapat } \\
\text { pasokan air }\end{array}$ & Mendanai & $\begin{array}{l}\text { Penggantian } \\
\text { pompa air yang } \\
\text { berkualitas baik } \\
\text { dan pemasangan } \\
\text { pompa yang } \\
\text { sesuai dengan } \\
\text { standart teknis } \\
\text { pemasangan. }\end{array}$ \\
\hline 9 & Operasional & $\begin{array}{l}\text { Terjadinya } \\
\text { banjir }\end{array}$ & $\begin{array}{l}\text { Mata air pada } \\
\text { sumber air induk } \\
\text { meluap karena } \\
\text { hujan turun dan } \\
\text { mengakibatkan }\end{array}$ & $\begin{array}{l}\text { Pasokan air } \\
\text { pada tandon } \\
\text { meluap dan } \\
\text { terbuang } \\
\text { serta air }\end{array}$ & $\begin{array}{l}\text { Menerimarisi } \\
\text { ko }\end{array}$ & $\begin{array}{l}\text { Karena hal } \\
\text { tersebut } \\
\text { disebabkan } \\
\text { karena kejadian } \\
\text { alam maka }\end{array}$ \\
\hline
\end{tabular}




\begin{tabular}{|c|c|c|c|c|c|c|}
\hline & & & $\begin{array}{l}\text { banjir pada titik } \\
\text { tertentu }\end{array}$ & $\begin{array}{l}\text { tercampur } \\
\text { dengan } \\
\text { tanah }\end{array}$ & & $\begin{array}{l}\text { keputusan yang } \\
\text { diambil sesuai } \\
\text { dengan teori buku } \\
\text { ISO } 31000 \text { yaitu } \\
\text { Menerima risiko } \\
\text { yang terjadi. }\end{array}$ \\
\hline 10 & Operasional & $\begin{array}{l}\text { Kesalahan } \\
\text { merekam } \\
\text { meteran air di } \\
\text { rumah } \\
\text { pelanggan }\end{array}$ & $\begin{array}{l}\text { Kurang } \\
\text { memadainya alat } \\
\text { pengukuran dan } \\
\text { apabila air mati } \\
\text { namun kran tetap } \\
\text { dibuka maka meter } \\
\text { air akan tetap } \\
\text { bertambah karena } \\
\text { yang keluar dari } \\
\text { pipa adalah angin }\end{array}$ & $\begin{array}{l}\text { Pelanggan } \\
\text { mendapat } \\
\text { tagihan } \\
\text { meteran air } \\
\text { terlalu } \\
\text { banyak atau } \\
\text { terlalu } \\
\text { sedikit }\end{array}$ & Mendanai & $\begin{array}{l}\text { Menyediakan alat } \\
\text { ukur yang } \\
\text { berkualitas baik } \\
\text { dan memberi } \\
\text { sosialisasi kepada } \\
\text { pelanggan apabila } \\
\text { air mati maka } \\
\text { keran air tidak } \\
\text { boleh dinyalakan. }\end{array}$ \\
\hline 11 & Operasional & $\begin{array}{l}\text { Pemasangan } \\
\text { pipa distribusi } \\
\text { tidak } \\
\text { memenuhi } \\
\text { spesifikasi }\end{array}$ & $\begin{array}{l}\text { Dilakukan tidak } \\
\text { sengaja oleh } \\
\text { kontraktor }\end{array}$ & $\begin{array}{l}\text { Dalam } \\
\text { pendistribus } \\
\text { ian pasokan } \\
\text { air pipa } \\
\text { mudah } \\
\text { bocor }\end{array}$ & Mendanai & $\begin{array}{l}\text { Perlu adanya } \\
\text { pengawasan saat } \\
\text { pemasangan pipa } \\
\text { oleh pekerja. }\end{array}$ \\
\hline 12 & Operasional & $\begin{array}{l}\text { Pemantauan } \\
\text { dengan } \\
\text { perangkat } \\
\text { lunak untuk } \\
\text { tekanan air } \\
\text { belum tersedia }\end{array}$ & Kurangnya dana & $\begin{array}{l}\text { Pengambila } \\
\mathrm{n} \text { keputusan } \\
\text { dalam } \\
\text { pengelolaan } \\
\text { air tidak } \\
\text { bisa tepat } \\
\text { waktu }\end{array}$ & $\begin{array}{l}\text { Menghilangk } \\
\text { an }\end{array}$ & $\begin{array}{l}\text { Pengajuan atau } \\
\text { pengusulan dana } \\
\text { kepada } \\
\text { pemerintah untuk } \\
\text { melakukan } \\
\text { pengadaan } \\
\text { pemantauan } \\
\text { dengan perangkat } \\
\text { lunak. }\end{array}$ \\
\hline 13 & Operasional & $\begin{array}{l}\text { Terjadi } \\
\text { koneksi ilegal }\end{array}$ & $\begin{array}{l}\text { Penambahan pipa } \\
\text { saluran air oleh } \\
\text { warga tanpa } \\
\text { sepengatahuan } \\
\text { pengelola }\end{array}$ & $\begin{array}{l}\text { Pasokan air } \\
\text { yang masuk } \\
\text { kepada } \\
\text { pelanggan } \\
\text { berkurang }\end{array}$ & Mengalihkan & $\begin{array}{l}\text { Pemantauan yang } \\
\text { lebih insentif lagi } \\
\text { oleh petugas dan } \\
\text { memberikan } \\
\text { sosialisasi kepada } \\
\text { masyrakat untuk } \\
\text { saling } \\
\text { mengingatkan dan } \\
\text { melaporkan } \\
\text { apabila ada }\end{array}$ \\
\hline
\end{tabular}




\begin{tabular}{|c|c|c|c|c|c|c|}
\hline & & & & & & $\begin{array}{l}\text { penambahan pipa } \\
\text { ilegal. }\end{array}$ \\
\hline 14 & Operasional & $\begin{array}{l}\text { Pasokan air } \\
\text { kelapangan } \\
\text { berhenti }\end{array}$ & $\begin{array}{l}\text { Pipa bocor, pipa } \\
\text { distribusi ke } \\
\text { pelanggan tidak } \\
\text { mengalir lancar dan } \\
\text { air keruh }\end{array}$ & $\begin{array}{l}\text { Pelanggan } \\
\text { mengeluh } \\
\text { kepada } \\
\text { pengelola }\end{array}$ & Mengalihkan & $\begin{array}{l}\text { Penanganan yang } \\
\text { cepat dari } \\
\text { petugas, dan } \\
\text { melakukan } \\
\text { komunikasi } \\
\text { kepada } \\
\text { masyarakat agar } \\
\text { tidak terjadi } \\
\text { keluhan dan } \\
\text { kesalahpahaman } \\
\text { yang } \\
\text { berkelanjutan. }\end{array}$ \\
\hline 15 & Operasional & $\begin{array}{l}\text { Meteran } \\
\text { pengukuran } \\
\text { air tandon } \\
\text { rusak }\end{array}$ & $\begin{array}{l}\text { Meteran sudah } \\
\text { telalu lama dan } \\
\text { sudah tua }\end{array}$ & $\begin{array}{l}\text { Jumlah air } \\
\text { yang masuk } \\
\text { ke tandon } \\
\text { tidak dapat } \\
\text { diukur atau } \\
\text { tidak } \\
\text { diketahui }\end{array}$ & Mendanai & $\begin{array}{l}\text { Penggantian } \\
\text { meteran tandon } \\
\text { dengan meteran } \\
\text { baru yang } \\
\text { memenuhi } \\
\text { standart. }\end{array}$ \\
\hline 16 & Operasional & $\begin{array}{l}\text { Sebagian } \\
\text { pelanggan } \\
\text { tidak dapat } \\
\text { pasokan air }\end{array}$ & $\begin{array}{l}\text { Berkurangnya } \\
\text { pasokan air pada } \\
\text { tandon saat musim } \\
\text { kemarau dan } \\
\text { adanya kebocoran } \\
\text { pipa distribusi. }\end{array}$ & $\begin{array}{l}\text { Berkurangn } \\
\text { ya pasokan } \\
\text { air yang } \\
\text { diperoleh } \\
\text { pelanggan } \\
\text { dan } \\
\text { pelanggan } \\
\text { mengeluh } \\
\text { kepada } \\
\text { pengelola }\end{array}$ & $\begin{array}{l}\text { Mandanaidan } \\
\text { Mengalihkan }\end{array}$ & $\begin{array}{l}\text { Melakukan } \\
\text { pembagian air } \\
\text { dengan sistem } \\
\text { bergiliran dan } \\
\text { penanganan } \\
\text { kebocoran pipa } \\
\text { secara cepat dan } \\
\text { sesuai prosedur } \\
\text { dan standart. }\end{array}$ \\
\hline 17 & Operasional & $\begin{array}{l}\text { Keluhan } \\
\text { pelanggan } \\
\text { tentang } \\
\text { pelayanan }\end{array}$ & $\begin{array}{l}\text { Terlambatnya } \\
\text { penanganan } \\
\text { pengelola ketika } \\
\text { ada kebocoran pipa } \\
\text { akibat galian } \\
\text { tanahataupipaterlin } \\
\text { daskendaraan yang } \\
\text { melintas. }\end{array}$ & $\begin{array}{l}\text { Pelanggan } \\
\text { mengalami } \\
\text { keterlambat } \\
\text { an } \\
\text { mendapatka } \\
\text { n pasokan } \\
\text { air }\end{array}$ & Mendanai & $\begin{array}{l}\text { Melakukan } \\
\text { penanganan } \\
\text { secara cepat dan } \\
\text { sesuai prosedur. }\end{array}$ \\
\hline
\end{tabular}




\begin{tabular}{|l|l|l|l|l|l|l|}
\hline 18 & Operasional & $\begin{array}{l}\text { Keluhan } \\
\text { pelanggan } \\
\text { tentang } \\
\text { pasokan air }\end{array}$ & $\begin{array}{l}\text { Air yang mengalir } \\
\text { ke pelanggan } \\
\text { berkurang karena } \\
\text { musim kemarau } \\
\text { atau terlambat } \\
\text { dalam pembenahan } \\
\text { pipa bocor }\end{array}$ & $\begin{array}{l}\text { Pelanggan } \\
\text { mendapat } \\
\text { giliran untuk } \\
\text { mendapatka } \\
\text { n air }\end{array}$ & $\begin{array}{l}\text { Mendanai } \\
\text { dan } \\
\text { mengalihkan }\end{array}$ & $\begin{array}{l}\text { Melakukan } \\
\text { pembagian air } \\
\text { dan melakukan } \\
\text { penanganan pipa } \\
\text { bocor dengan } \\
\text { cepat. }\end{array}$ \\
\hline
\end{tabular}

\section{F. KESIMPULAN}

Dari hasil analisis pada Pengelolaan sumber air di Sumberdodol terdapat 1 risiko yang berada pada zona merah yang artinya harus mendapatkan penanganan dengan segera agar tidak mengganggu proses distribusi air. Terdapat 7 risiko yang berada pada zona kuning dan 10 risiko pada zona hijau dimana hal tersebut memiliki potensi risiko yang lebih rendah.

Adapun potensi risiko yang berada pada zona merah yang harus dilakukan penanganan segera adalah kebocoran distribusi pada pengelolaan air di Sumberdodol. Upaya penangnan sudah dilakukan dengan baik oleh pengelola air yaitu POKMAS Tirto Rahayu.

\section{G. DAFTAR PUSTAKA}

Leo J \& Victor Riwu. 2018. Panduan manajemen Risiko Berbasis ISO 31000. Jakarta : Penerbit Gramedia. 246 Hlm, ISBN: 979-442-271-1.

Abisay, T.G., \&Nurhadi.2013. Manajemen Resiko pada Bandara Soekarno Hatta Berbasis ISO 31000. Jurnal Teknik Industri, 14 (2), 116-129.

Dewi, D. 2012. Penerapan Sistem Manajemen Resiko pada Industri Nasional sebagai Masukan untuk Program PLTN. Prosiding Seminar Nasional Pengembangan Energi Nuklir V, 2012, Jakarta, Indonesia. Hal:68-76, ISSN: 1979-1208.

Febriyanti, A., \&Hidayanto, B.C. 2012. Manajemen Resiko pada Pengelolaan Data di Bagian Pengolahan Data PT Petrokimia Gresik. Jurnal Teknik Pomits, 1 (1), 1-6.

Hanggraeni, D. 2015. Enterprise Risk Management and Good Corporate Goverment. Jakarta. Penerbit Universitas Indonesia. ISBN: 978-979456-555-1. 
Hanafi, M.M. 2014. Manajemen Risiko. Yogyakarta: Penerbit UPPM STIM YKP. ISBN: 878-879-3532-61-5.

Li Guo. 2015. Implementation of a Risk Management Plan in a Hospital Operating Room. Internasional Journal of Nursing Science. ElsevierScienceDirect., 345-354.

Zainal, Syafrudin \& Moenawar.2017. Design of Risk Management Based on ISO 31000 in PDAM Tirta Meulaboh. Banda Aceh. Universitas : Teuku Umar University, Meulaboh \& Syiah Kuala University, Banda Aceh, Indonesia. 